\title{
Comunidade sem portas: imaginando o Cariri a partir de um bar de fim de noite
}

Roberto Marques (URCA)
INTRODUÇÃ O

Em meados da década de 70, Bourdieu, Foucault e Said dotaram a discussão sobre espacialidades em Ciências Sociais de um novo caráter, em que os limites entre real e representação - a justa apresentação daquele por esta em um percurso aproximativo - será tomada como uma falsa questão. Malgrado as distintas posições teóricas marcadas por ocasionais confluências, para esses autores, descrever é re(a)presentar a realidade, dotando-a de legitimidade.

Em um texto clássico sobre o tema, Bourdieu (1998) concebe o regionalismo como um caso particular de instituição de uma identidade social, pautada nas disputas de reconhecimento de representações objetais (emblemas, bandeiras, insígnias) ou atos que têm em vista determinar a representação mental que os outros podem ter destas propriedades e dos seus portadores. $\mathrm{O}$ autor chama a atenção para a importância dos expedientes de reconhecimento da autoridade daquele que anuncia a divisão social que desenha limites e espacializa o real, assim como para o reconhecimento dos objetos anunciados pelo grupo a que se anuncia tal identidade. No Brasil, tais ideias foram utilizadas, por exemplo, em Penna (1992) que define regionalismo como "o processo que torna o espaço significativo (...) ao tornar uma região socialmente visível, criando uma forma de representação difundida e aceita" (1992:19).

Said (1990), em seu estudo sobre o orientalismo, chama a atenção para o fato de tal visibilidade possuir um caráter prático de dominação. Assim, a metodologia empregada pelo autor "não depende [ria] de um exaustivo catálogo de textos (...) nem de um conjunto claramente delimitado de textos, autores e ideias que juntos formam o cânone orientalista" (1990: 16). Ao contrário, já que seu objeto não é a verdade sobre o Oriente, ou a aproximação e distância que um conjunto de textos guarda em relação a uma determinada materialidade ou espacialidade, caberia ao 
autor trabalhar sobre "um conjunto de generalizações históricas" (Said 1990: 16) sobre o Oriente e como esse conjunto de generalizações efetiva jogos de dominação deste espaço pelo Ocidente.

Em ambos os autores, o saber acadêmico como autoridade legitimada é parte integrante nessa disputa sobre as dizibilidades e definições de identidades sociais (Bourdieu 1998). Como nos diz Said, "mesmo que não sobreviva como antigamente, o orientalismo continua a viver academicamente através de suas doutrinas e teses sobre o Oriente e o oriental" (1990: 14). Posição referendada por Foucault (apud Dreifus e Rabinow 2010), ao se furtar de recuperar a autointerpretação cotidiana dos homens. Como nos ensinam Dreifus e Rabinow: "A Foucault interessa apenas o que chamaremos de ato de fala sérios: os que os peritos dizem quando falam com peritos" (2010: XXIII).

É notório como, no Brasil, as posições de Said e Foucault em torno da discussão sobre espaço foram tomadas para pensar o Nordeste como objeto privilegiado. Objeto dependente, como todos os outros, de "generalizações históricas", "catálogos de textos" (Said 1990), "fantasias sociais, culturais e científicas que definiram o Nordeste" (Rago 2001: 14) a partir das primeiras décadas do século XX (Albuquerque Jr. 2001).

Said (1990) nos ensina que o local descrito pelos nativos não pode ser confundido com o real, independente dos textos e relações que o definem. Dessa forma, sabendo que toda dizibilidade é dependente de imagens negociadas (Clifford 2002), quais os efeitos de descrição de uma região ao sul do Ceará a partir de um local particularmente indistinto, um bar de fim de noite?

Os espaços aqui descritos serão pensados a partir de uma tentativa de fricção. Interessa-nos entrevê-los não somente como cenário de atualização para oposições marcantes do desenvolvimento teórico das ciências sociais, tais como: urbano- rural, pessoalidade-impessoalidade, mar-sertão; mas como dados operacionais da forma de pensamento que diz respeito a essas e outras oposições operadas pelos sujeitos. Nestas, categorias tais como anonimato, espacialidades e pessoalidade operam de forma bastante singular.

Tomo como local de análise etnográfica um bar de fim de noite em uma região ao sul do Ceará, cerca de 600 quilômetros distante da capital daquele estado, conhecida como Cariri. Ali, como tento deixar claro a seguir, engendram-se novos desafios para a escrita antropológica. Apressemo-nos um pouco: Vamos ao Guanabara!

O Restaurante Guanabara, ou o Neném, fica localizado na cidade de Crato, na Rua Monsenhor Esmeraldo, tendo à sua direita a Rua Tristão Gonçalves, também conhecida como "Rua da Vala", e à sua esquerda a Rua Senador Pompeu ou "Rua do Banco do Brasil" ou ainda "Rua da Farmácia Gentil"1. Seu salão em formato de ' $L$ ' está atualmente pintado de verde oliva, com diferentes efeitos de textura. Ao longo das paredes, em toda a extensão do restaurante, corre um listelo de espelhos que permite aos clientes visualizarem quase todos que estejam presentes no bar sentados nas outras mesas, sem que seja necessário olhar diretamente para eles. 


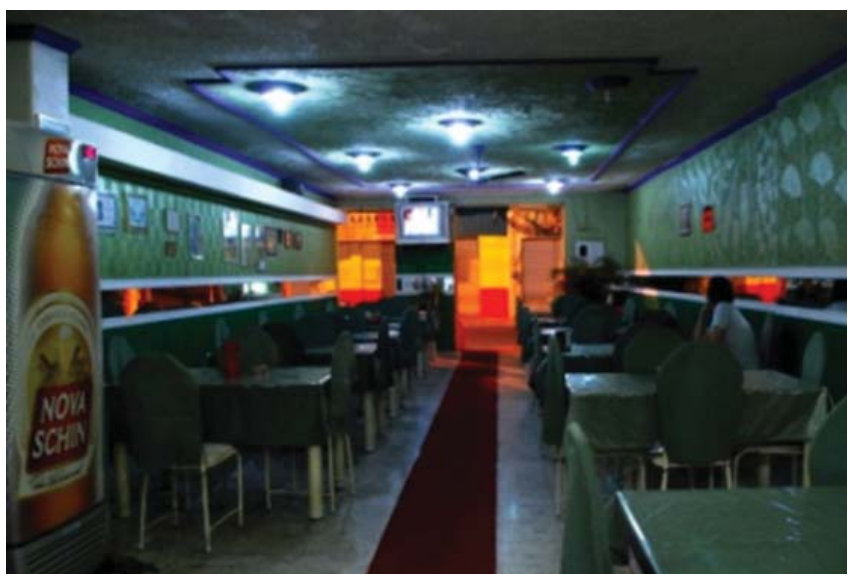

Salão principal do Restaurante Guanabara

Acima dos espelhos, sobre as paredes texturizadas, fotos e reportagens contam a história do bar. A iluminação é direta, com luzes fluorescentes. A entrada do restaurante é ornada por um tapete vinho que segue em direção ao balcão onde funciona, ao mesmo tempo, a entrega de pedidos da cozinha para os garçons e o caixa para pagamento das contas. Ao fundo, descansam, sobre as prateleiras, dezenas de garrafas de uísque, rum e conhaque de marcas populares. A grande quantidade de garrafas e a variedade de suas cores conferem ao local uma impressão de riqueza e abundância, independente do valor ou da qualidade das bebidas ali dispostas. Ao final do salão de entrada, à esquerda, há um ambiente mais reservado, embora não separado por porta ou divisórias, com decoração idêntica ao ambiente principal. Dali não se vê, no entanto, a televisão, colocada no alto, como que emoldurada pela simetria das duas vias de acesso ao restaurante. Além disso, diferentemente do salão principal, esse ambiente reservado é ornado por lustres pendendo do teto.
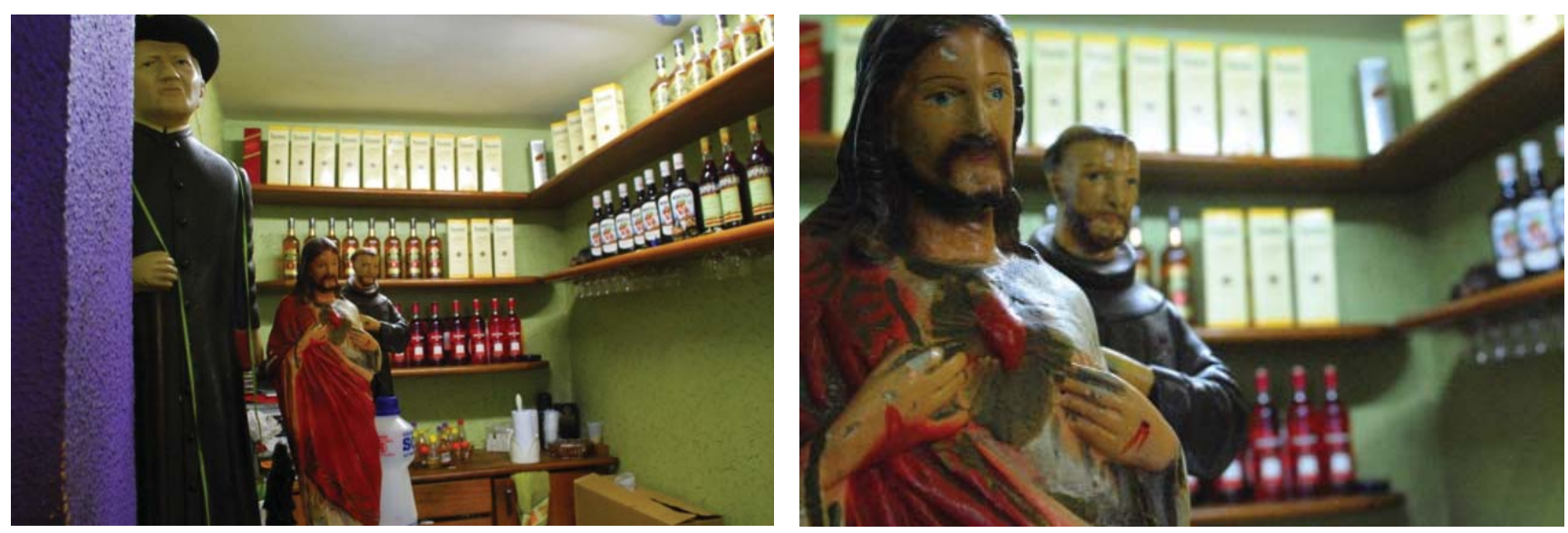

Prateleiras de bebidas ao fundo do balcão do Restaurante Guanabara 
O restaurante não possui portas. Essa é a característica principal do Guanabara. Ela será realçada a qualquer pessoa que esteja ali pela primeira vez, seja ao jovem frequentador em suas primeiras noitadas, seja ao visitante de outras cidades. Na placa, acima da entrada do restaurante, lê-se: "52 anos de tradição" e, logo abaixo: "24 horas de portas abertas". Não tendo portas, pode-se pedir a toda hora do dia ou da noite qualquer um dos pratos do tradicional cardápio do restaurante, sendo o carro-chefe o Filé à parmegiana. À noite ou no início da manhã, tem destaque, o "caldo" de carne moída, verdura e ovo, acompanhado por fatias de pão e margarina. Além desses, há uma variedade de pratos de carnes, peixes e aves, alguns tira-gostos e sanduíches, e certa diversidade de bebidas. Os pratos são servidos durante o dia por um garçom e à noite por um serviço de dois ou três serviçais, todos vestidos de camisa de mangas compridas brancas e gravatas-borboleta pretas já bastante gastas, combinando com a calça e os sapatos.

Como nos diz a placa em sua faixada, o estabelecimento contabilizou, no início de 2010, 52 anos de existência. Seu proprietário, Francisco Feitosa², o "Neném", frequenta o restaurante à noite, vestido formalmente com calça de tergal, sapato social frequentemente branco, camisa de mangas curtas de pano passado e cordão de ouro no pescoço. Com o fecho aberto, seu relógio pende por sobre a mão esquerda. Neném, que idealizou e inaugurou o bar, anda de um lado para o outro por sobre o tapete vinho, às vezes conversa com os clientes mais íntimos em sua mesa próxima ao balcão ou se senta em uma cadeira plástica em frente ao bar. Sua presença é alvo de comentários e saudações. Sua mesa, ao final do salão principal, possui uma toalha diferente das demais. Nela sentam-se, na hora do almoço, seus familiares, filhos, filhas; e à noite os antigos frequentadores do Guanabara, boêmios de carreira, garotas de programa, damas da noite. Ocasionalmente, naquela mesma mesa sentam-se também bêbados, desatentos à marcação de regras do lugar.

Quando, ao longo da noite, as caixas de som tocam Altemar Dutra ou outros cantores de seresta, todos saúdam a presença de Neném. Durante o dia, suas filhas, já adultas, se alternam no caixa. À mesa da família é comum ver almoçarem filhas, filhos, netos e esposa. No início da noite, seu filho senta-se à mesa, observando o Bar.

Para que se possa pensar que lugar ocupa o Guanabara em meio a esse cenário urbano, falemos um pouco sobre a cidade de Crato. Atualmente com cerca de $122.000^{3}$ habitantes, a cidade forma em conjunto com Juazeiro do Norte e Barbalha, o centro cultural, econômico e político do Cariri. Pode-se pensar a região a partir de uma tensão entre horizontalidade e verticalidade: enquanto as cidades de Crato e Barbalha estariam amparadas pela tradição familiar, nas monoculturas de cana de açúcar e algodão, e na pecuária - em uma dizibilidade que prioriza o uso e apego a terra e a ideia de origem como tradição; Juazeiro do Norte ancoraria sua força econômica e simbólica no deslocamento constate de romeiros para a terra do Padre Cícero e no comércio, rendendo-lhe nas últimas décadas um crescimento populacional bastante acelerado, como já demonstraram, por exemplo, Della Cava (1976) e Facó (2009) ${ }^{4}$.

A distância da região em relação à capital do Ceará, bem como sua proximidade aos estados de Pernambuco, Paraíba e Piauí, reitera a necessidade constate de a definir como uma realidade particular a partir de oposições 
como litoral e sertão, capital e interior, dentre outras; ao mesmo tempo em que lhe conferem um caráter de variedade, trânsito e entre fronteiras, de difícil e instigante apreensão.

As observações de campo aqui relatadas são um recorte da pesquisa empreendida na região entre os anos de 2007 e 2011. Essa pesquisa priorizou o ambiente das festas de forró eletrônico, detendo-se em seis cidades do interior do Ceará. À medida que a festa foi revelando suas relações com o cotidiano das cidades, passamos a observar, na cidade de Crato, outros locais de formação de pares e grupos que se mantinham durante a festa. Desta forma, espraiamos a observação de campo para ambientes como academias de ginástica onde se antecipavam as festas, encontros em bares e chalés em finais de semana ou ainda em bares de fim de noite, para onde as pessoas costumam seguir logo após a festa (Marques 2011). Utilizo, assim, o Guanabara para refletir sobre uma forma de pensamento presente no Cariri, ainda que muito distante da usual reflexão sobre a região a partir dos seus signos identitários (Albuquerque Jr. 2001).

\section{NEM ANTROPOLOGIA DE BAIRRO, NEM ANTROPOLOGIA DA NOITE: O GUANABARA EM QUESTÃO}

Não será exagero afirmar que o estudo de bares iniciou-se com a Antropologia Urbana. Silva (1969) afirma: "Até onde estou informado, o botequim nunca foi considerado objeto relevante de estudo. Por isso, a ausência de literatura a respeito é quase total" ${ }^{5}$ (1969: 160). Quarenta anos depois, encontramo-nos em situação bastante diferente: multiplicam-se os artigos e teses ambientadas em bares ou que tem nos bares um de seus campos prioritários de observação. Poderíamos, de forma em absoluto exaustiva, citar: Lacombe (2005), Benítez (2007), Facchini (2008), França (2009). Essa situação, que possibilita refletir sobre grupos sociais a partir de espaços de lazer e consumo, se espraia também para as boates (Gaspar 1985; Oliveira 2006) e as ruas (Perlongher 1987; Souza 2003) ${ }^{6}$. Como nos diz Silva:

Os motivos que levam os consumidores a procurar cada um desses estabelecimentos são diferentes, de modo que as funções que desempenham- isto é, o 'significado' que tem para os frequentadores- também variam muito (1969: 161).

Faz-se necessário pensar também os motivos que, contemporaneamente, mais que há quarenta anos, levam os antropólogos a escolher esses espaços como campo de pesquisa. Perlongher, em meados da década de 80, chama a atenção: “É preciso reconhecer (...) que a moderna antropologia brasileira acabou desenvolvendo certa aversão pelos espaços abertos, preferindo abordar comunidades ou grupos mais ou menos fechados". E, posteriormente: "Concomitantemente a essa opção, as pesquisas antropológicas preferem dirigir-se às camadas menos favorecidas da população (...) poder-se-ia dizer que os estudos sociais urbanos privilegiam o bairro em relação ao mundo da noite" (Perlongher 1984: 2-3).

O fato de que grande parte dos trabalhos acima citados, realizados em "casas de bebidas" (Silva 1969), analisa e caracteriza populações específicas chamando atenção para suas formas de classificação e peculiaridades 
de suas gramáticas, faz-nos perceber que ao desafio proposto por Silva, quarenta anos atrás, foram colados outros dois: a pesquisa das camadas menos favorecidas, uma "antropologia dos bairros" conforme comentado acima por Perlongher (1987); e o projeto lançado por Peter Fry (1982), de elaboração de uma "antropologia sexual". Essa última colagem conflui para a ideia de sexualidade como verdade sobre o sujeito, à importância da territorialidade e do consumo para a composição de uma comunidade 7 . Um breve relato sobre o Guanabara nos ajudará a pensar os limites dessa forma de tratamento das questões.

10.04.2009. Chegamos ao Guanabara, Lima Júnior ${ }^{8}$ e eu, por volta das 21 horas. Na televisão, sobre a entrada do bar, passava a novela das 20 horas. Lembro um dia em que alguém comentou ironicamente: “Está vendo como este é um bar familiar? As pessoas vêm para assistir a novela!". Naquela noite não havia música ambiente. No salão principal cerca de dez mesas estavam sendo utilizadas. A primeira mesa à direita era ocupada por três mulheres e dois homens. Elas compartilhavam entre si um único cigarro, circulando-o de mão em mão. Usavam shorts surrados, chinelos e camisetas sem mangas, cabelos presos atrás da cabeça, à altura da nuca. Acompanhando-as, um rapaz de bigode, alto, jovem, e outro um pouco mais velho. Embora compartilhassem a mesma mesa, homens e mulheres não conversavam entre si, como se estivessem em mesas distintas. Raramente o assunto ultrapassava a barreira invisível entre os dois grupos.

Apontando essa mesa especificamente, perguntei a Lima Junior: "De onde vieram?". "Provavelmente, do Seminário ou do Alto da Sé" - respondeu Lima Júnior, referindo-se a bairros populares da cidade de Crato. "Vieram ter um dia de lazer", disse, chamando a atenção para o fato de uma das mulheres da mesa usar fivelas no cabelo. "Quando se arrumam assim é porque vão para um dia especial de lazer"9.

A mesa ao lado era ocupada por um rapaz com fortes trejeitos ${ }^{10}$, mais arrumado que os outros freqüentadores do bar, vestido com calça jeans apertada e camisa de listras bastante ajustada ao corpo. Seu cabelo tinha mechas louras, em um efeito chamado 'luzes'. Estava acompanhado de uma moça, também bastante bem vestida, que falava expressiva e frequentemente ao celular. Ao longo da noite, chegou um terceiro rapaz para essa mesa. Também com luzes no cabelo, vestia camiseta e calça brancas bastante apertadas e tinha uma tatuagem na altura da nuca. O primeiro rapaz levantava ocasionalmente para ir ao banheiro, rebolando muito no percurso de ida e de volta, chamando atenção para si ao longo do seu trajeto no tapete vinho.

Duas mesas adiante havia 03 homens na faixa etária de 40 a 50 anos, já bastante alcoolizados. Um deles, meu conhecido de algum tempo, aproximou-se da mesa em que eu e Lima Junior estávamos e disse que estavam na "serra" desde ontem, beberam muita cachaça lá e resolveram vir ao Guanabara. Na mesa atrás da minha, alguém tomava caldo. Na mesa seguinte, um de meus ex-alunos, com cerca de 30 anos de idade, bebia cerveja e jantava sozinho. Em seguida, pegou a mochila e se retirou. 


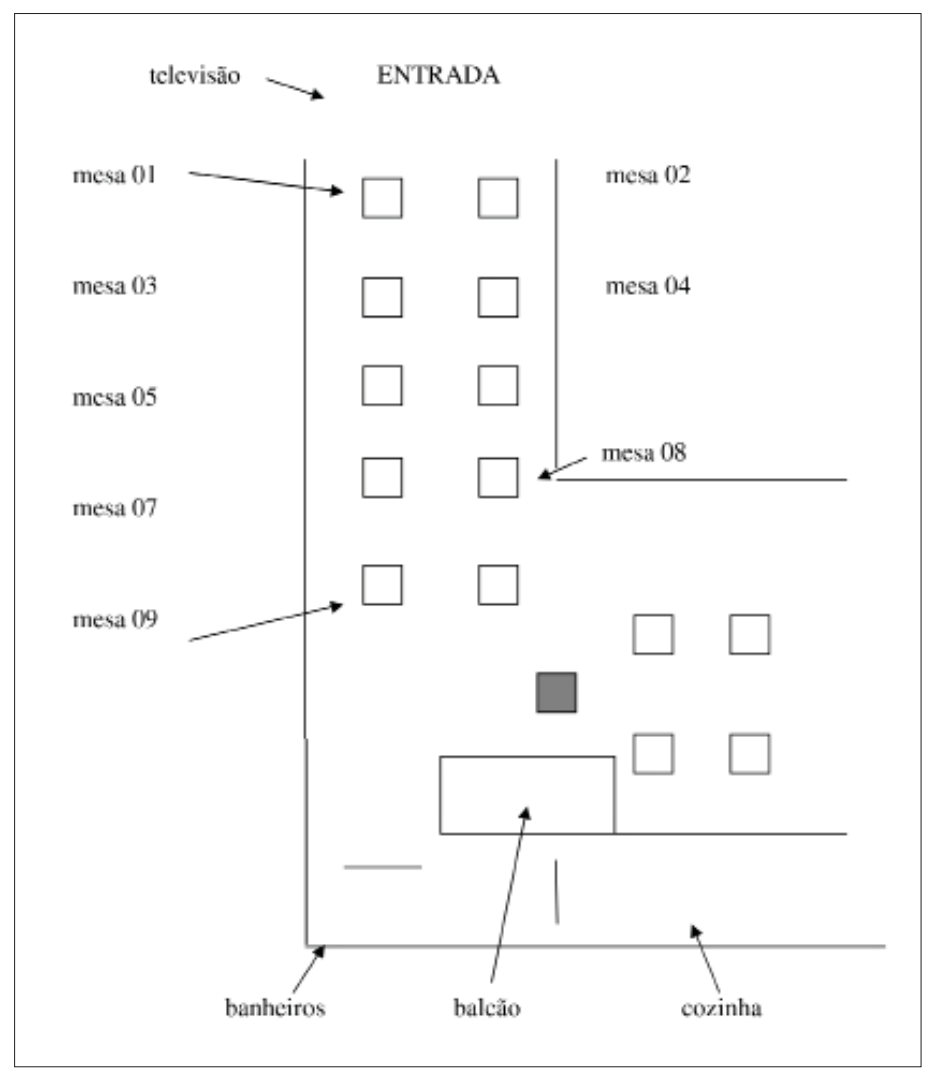

Localização das mesas no Restaurante Guanabara

Havia mesas ocupadas no espaço mais reservado do bar, mas, de onde eu estava só era possível ver uma moça morena acompanhada de um senhor de cabelos grisalhos e compridos, bem mais velho que sua companheira. Ao longo da noite chegaram, para a mesa ao lado da minha, dois casais: uma universitária com óculos grandes e vermelhos, usava vestido longo, de alças, com estampa indiana, e um rapaz de cavanhaque, usando calça jeans desbotada; uma moça branca de short curto, estilo balonê, camisa ajustada na parte dos seios e solta à altura da barriga e saltos altos, acompanhada de um rapaz alto e gordo, que falava em tom elevado com a mesa seguinte e trocava provocações jocosas. Este último casal estava com a filha, de não mais de quatro anos, que transitava entre os membros da mesa.

A quantidade de pessoas bêbadas em cada mesa, as mulheres vestidas de forma casual e usando chinelos de dedo, a moça na mesa dos rapazes com trejeitos afeminados falando alto ao telefone, conferiam um ar boêmio ao bar. Ao mesmo tempo, a ausência de música e a televisão transmitindo novela nos faziam sentir em casa, em um clima absolutamente banal e cotidiano. 
É bastante clara a distinção entre essa experiência de campo e as relatadas por Silva (1969), França (2009), Perlongher (1987) ou Souza (2003). Não há aqui a possibilidade de recortes do território etnografado por classe econômica ou prática sexual. O Guanabara não pode ser categorizado como um bar "de bairro" ou a partir das preferências de um público específico ${ }^{11}$. Ao contrário, além do fato de não ter portas, sua característica principal é que lá encontramos "todo tipo de gente". Após três anos de etnografia na cidade de Crato e no Cariri, ao longo de várias noites no Guanabara, já assisti casais apaixonados dividindo matematicamente um Filé à parmegiana, provavelmente em comemoração a alguma data ou evento; já estive ao final de um baile à fantasia de pré-carnaval chamado Carnaval da Saudade ${ }^{12}$ e vi a Mulher Maravilha, o Peter Pan e odaliscas entrando no bar; ou ainda acadêmicos de medicina, ao final de um baile de formatura. Acompanhei também uma noite em que os atores globais Luiz Melo e Guilherme Leme compartilhavam a mesa com a produção das peças que haviam apresentado, enquanto eram abraçados por louras de shorts curtos, visivelmente alcoolizadas. Ao mesmo tempo, em outra mesa, negros de bonés, moletons abertos e correntes prateadas de argolas grossas no pescoço, reclamavam que a cerveja custava o mesmo para eles ou para os atores e que, portanto, não viam motivo para não serem atendidos rapidamente.

Estando na região central da cidade e não possuindo portas, o Guanabara possui um público particularmente indistinto. Assim, mais que descrever o bar, as observações aqui realizadas buscam caracterizar o ambiente a partir da ideia de colagem entre pares dessemelhantes. Essa colagem que dá lugar a uma forma de pensamento ali presente bastante distinta da ideia usual de identidade nordestina (Albuquerque Jr. 2001; Penna 1992), requer recursos teórico-metodológicos que não descrevam o ambiente etnografado, os frequentadores desse ambiente ou a região em que se localizam, como a descrição de uma "matemática de números inteiros" (Strathern 2005: 67-68).

Essa indistinção, ao tempo que parece ofuscar as imagens mais usuais sobre o Cariri, não as suplanta. Antes de aprofundar esse argumento, no entanto, pensemos que novos signos de identificação se esboçam no Guanabara. 

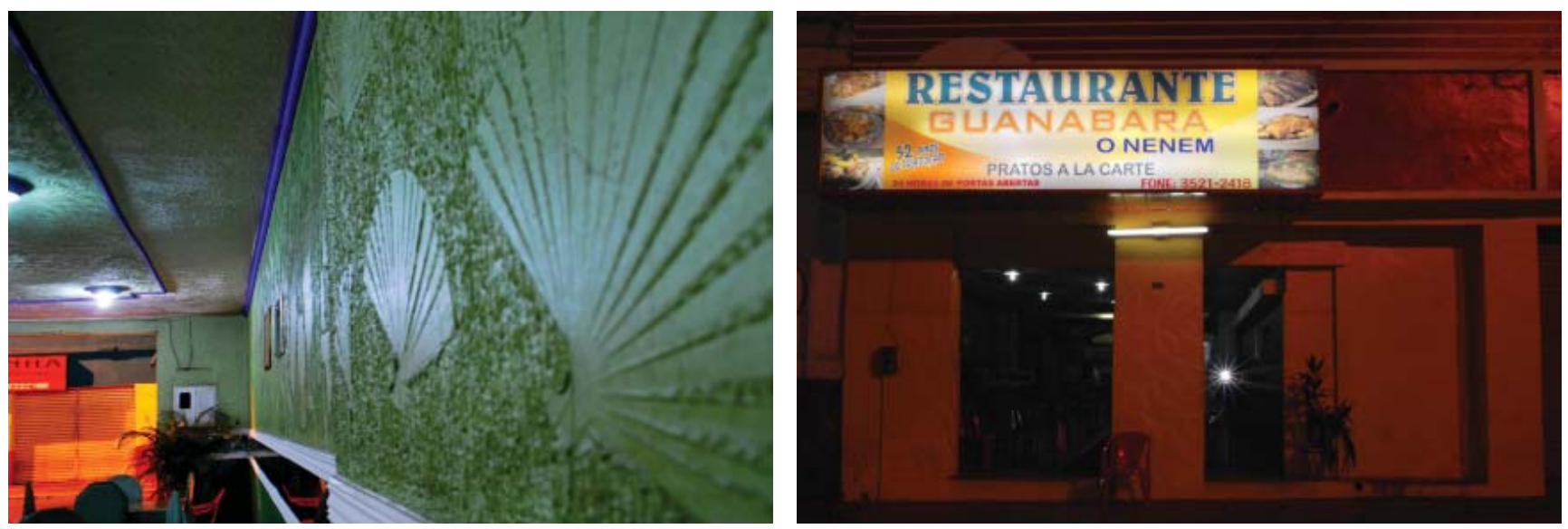

Detalhes e fachada do Restaurante Guanabara

Apesar da ausência de portas, o Guanabara possui linhas de força que organizam as narrativas sobre o bar. Na noite descrita acima, acompanhado de Lima Junior, um dos clientes se sentou à mesa conosco e começou a contar que "o bar não é mais o que costumava ser":

Aqui, cada um tinha um tratamento personalizado. Chegava um senador, tinha um tratamento personalizado! Chegava uma prostituta, tinha um tratamento personalizado! Eu chegava, tinha um tratamento personalizado! E ai de quem desrespeitasse as garotas de programa!

Continuou sua narrativa dizendo que Neném agora pouco frequentava o bar, que estava muito doente. Retruquei, afirmando que o via sempre ali. Ele, parecendo não ouvir o que eu dissera, continuou afirmando que o bar não é mais o que era: "Agora é outra coisa!". Alguns meses depois, em uma noite em que Neném estava no bar, ouvi de um cliente que conversava no balcão: "Neném! O último boêmio do Crato!" - Neném, de camisa passada, sapatos brancos, cabelo vaselinado, sorria. A origem boêmia do bar é também relembrada por Jaime, filho do proprietário:

Antigamente, o bar ficava na Rua da Vala. Naquela época, a iluminação pública era feita por candeeiros, acesos um a um e alimentados a gás. A proximidade das casas de prostituição do bairro do "gesso"22 garantia a frequência do bar. Depois o bar mudou-se para ali [referindo-se à localização atual do bar, na Rua Monsenhor Esmeraldo, onde ocorreu essa conversa].

Jaime continua o relato, afirmando que ali se vendem 500 filés a parmegiana por mês, enquanto outros locais da cidade vendem entre 100 e 150. Mostrando a imagem do Padre Cícero sobre o balcão, afirmou ser aquela a mesma imagem desde a inauguração do bar: "É que o bar conta com muita proteção! Porque todo esse tempo não houve uma confusão aqui! Um local frequentado por bêbados, artistas, drogados e nunca aconteceu uma confusão!". 
Em entrevista, Neto, um cliente habitual, diz ser representante da terceira geração de familiares que frequenta o Restaurante:

Meu avô por parte de mãe foi colega de Neném na época da boêmia... Saía pelos cabarés da vida atrás de mulher pra dançar tango. Meu avô era boêmio, como Neném também foi um boêmio. Meu pai também frequentava muito lá. Eu, menino velho, ia pras viradas de noite com meu pai e depois dele, veio eu. Se bem que já foi até a quarta geração, que eu já levei meu filho e minhas filhas para jantarem lá! (...) Se bem que naquela época, o Restaurante Guanabara era uma coisa assim totalmente diferente de hoje... O Restaurante Guanabara era uma coisa assim, eu não gosto nem de utilizar essa palavra! Mas tinha... A frequência do Restaurante Guanabara era um pessoal com [maior] poder aquisitivo! Havia poucos [que não tinham dinheiro], como é o caso do meu pai, mas hoje você vê que o Restaurante Guanabara está assim tão misturado! Que eu acho até melhor por causa disso! Tão eclético, que você vai numa mesa conversa sobre Nietzsche, vai a outra conversa sobre Forró, Rapariga, tem tudo isso... Agora tá bom! Naquela época não! Hoje em dia o pessoal diz que vai pro Neném ver se arruma uma coisinha, como [se fosse] um ponto de encontro. Ai teve essa grande modificação.

Eu: Você acha que era diferente na época do teu pai...

Neto: Na época do meu pai tinha [essa prática], mas o pessoal não ia lá para aventurar alguma coisa (...) Alguns deles pegavam as meretrizes, saíam à noite e passavam depois no Guanabara para jantar. Hoje, as pessoas vão aventurar lá!(...) Se bem que tem a coisa de ser também como antigamente... De ser um ambiente familiar também! Eu: Você diz que era um ambiente mais elitizado... Mas se eu não estou enganado o fato do restaurante ser ali é pela proximidade da Rua da Vala e a proximidade com o Gesso.

Neto: Exatamente, o Restaurante está ali em um ponto estratégico. Na Rua da Vala ficavam os bordéis, no final do Gesso também ficavam os bordéis. Então ali era um canto bem estratégico!

Para analisar a fala de Neto, retomo a tensão entre horizontalidade e verticalidade citada acima. Para ele, algo do valor do Guanabara repousa sobre a sucessão de gerações que o frequentaram e o frequentam até hoje. Se essa memória parece descrever uma linha vertical, esse raciocínio é alternado com outra forma de valorização do local: sua indistinção, a variedade de público e interesses que o povoam. Uma linha horizontal que complexifica o espaço e a linearidade da fala de Neto: esse "ecletismo" é um valor positivo ou uma traição das gerações que fizeram o Guanabara? O Guanabara é "outra coisa agora" ou a continuação de um projeto de boemia?

Por outro lado, se falamos do Guanabara para rever falas e oposições que povoam o Cariri, vale considerar outra difícil equação: as relações de pessoalidade ali guardadas. É certo que as narrativas sobre o Guanabara e sua confluência com a memória da cidade encontram-se ancoradas no personagem "Neném". A partir disso, poderíamos fazer eco a Prado (1997) quando afirma ser a pessoalidade uma característica das pequenas cidades, estando os estabelecimentos vinculados aos nomes de seus proprietários ou representantes. É possível que tal efeito, analisado pela autora em Cunha ${ }^{14}$ na década de 80 , pudesse ser percebido também em Crato na mesma época. No entanto, interessa-nos aqui perceber como essa "pessoalidade" não se contrapõe, em nossa etnografia, a encenações de anonimato, conferindo territórios de luz e sombra aos sujeitos, permitindo que esses se reinventem na sua relação com esses territórios. Para compreender isso, é necessário que situemos o Guanabara para além das narrativas de seus freqüentadores, para além da oposição entre as ideias de pessoalidade e impessoalidade.

Falar sobre o Guanabara, esse bar de fim de noite em uma cidade no interior do Ceará, lembra-nos a dificuldade de localizar experiências excessivamente distintas das dizibilidades usuais sobre a região Nordeste, 
usualmente apreendido como outro da nação. Ora, como nos lembra Pratt (1999a; 1999b), há muitos "outros" possíveis nas margens. Ao mesmo tempo, parece-me aqui inútil falar do Guanabara sem localizar o Cariri e as linhas de força que organizam as narrativas a seu respeito - ou para ser mais exato, pensar o que as relações descritas no Guanabara dizem sobre o Cariri.

\section{CARIRI, NÃO COMO CENÁRIO, MAS COMO DADO RELACIONAL DA EQUAÇÃO}

Será possível escrever sobre a região do Cariri sem descrevê-la como uma área situada ao sul do Ceará, composta por 28 municípios, dentre os quais se destacam as cidades de Crato, Juazeiro do Norte e Barbalha como centro econômico, político e cultural? O conjunto temático utilizado para identificar a região do Cariri remete à noção de um lugar ermo, campo de tradições, espaço atualizador da ideia de Nordeste. Imagens associadas à Patativa do Assaré, Luiz Gonzaga e Padre Cícero ${ }^{15}$ refletem essas ideias nacional e internacionalmente de forma mais efetiva. Tem-se com eles, como já nos demonstraram Albuquerque Jr. (2001), Marques (2004a) e Martins (2003), uma ficção organicista (Strathern 2006) de um espaço autorreferido, independente das relações e redes sociais ali estabelecidas, cuja potência narrativa é estancada pela força dos signos identitários da ideia de Nordeste - seca, cangaço, religiosidade popular e coronelismo (Albuquerque Jr. 2001). Não desejamos aqui reestabelecer a oposição entre um território supostamente real e suas imagens. Desejamos antes perceber como tais imagens são agenciadas em sua interação com outras imagens, em contextos que esgarçam seus termos, revelando territórios e sujeitos complexos maquinados por essa tensão. 


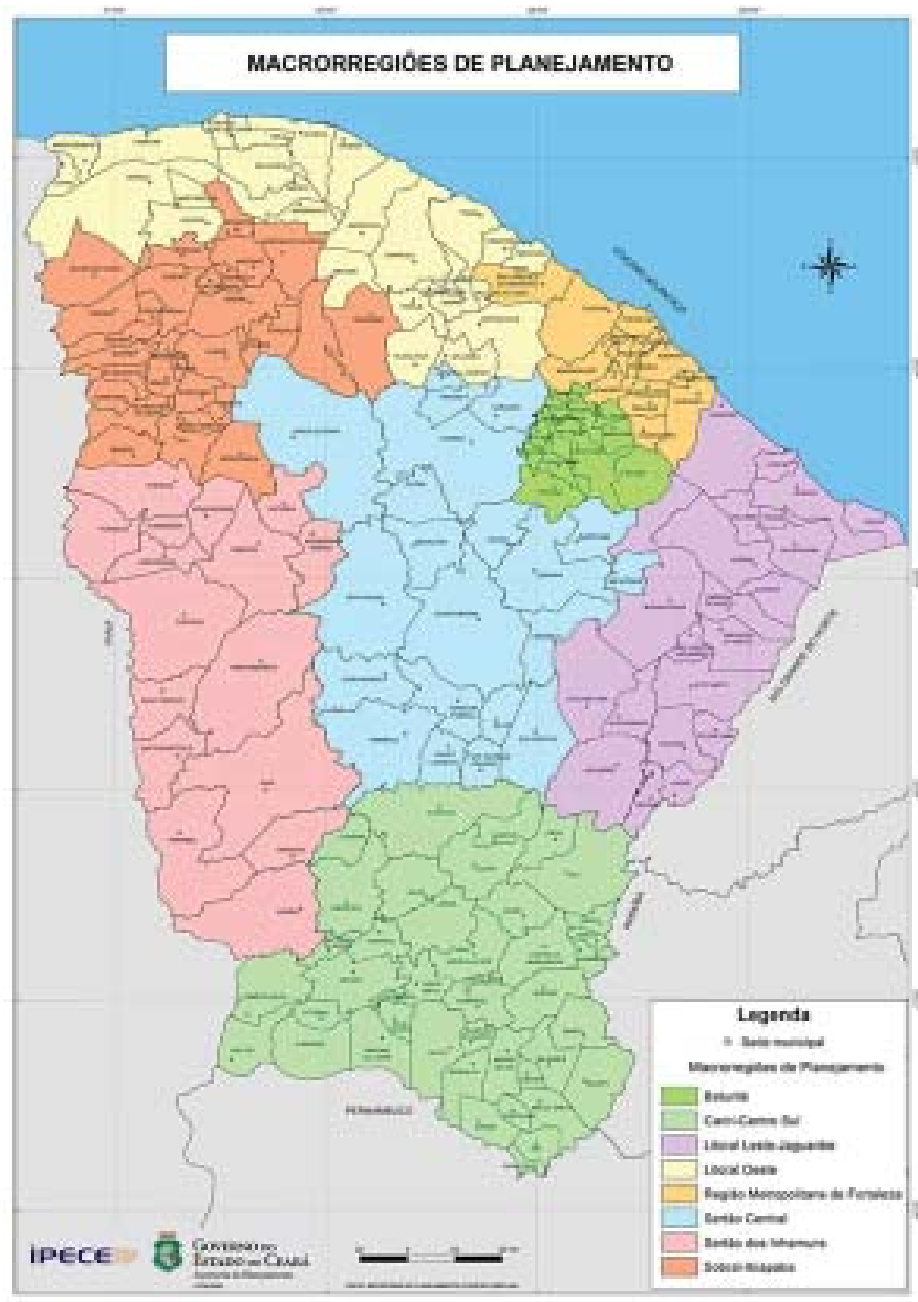

Macrorregiões de planejamento do estado do Ceará. Fonte: IPECE, 2011.

Como afirmei anteriormente, embora as ideias de linhagens familiares, posse de terra e tradição desenhem uma linha vertical que aproxima o Cariri de um Nordeste ancestral com "temporalidades indefinidas" (Woortmann 1995), o fenômeno conhecido como Milagre do Padre Cícero, no início do século XX (Della Cava 1976; Paz 2011; Cordeiro 2011; Barbosa 2007; Marques 2009), transformou a paisagem local. O fortalecimento econômico e simbólico de Juazeiro do Norte, o deslocamento incessante de romeiros, a riqueza pautada na fé e não na posse de terra, possibilitaram novas narrativas de significação local. Em tensão constante com a verticalidade da tradição impõe-se a horizontalidade do deslocamento ${ }^{16}$. 
Observando a região de dentro, a partir de sujeitos e realidades concretas, pareceu-me possível entrever algo diferente do Cariri conforme narrado a partir desse engenho atemporal de signos. Outras imagens ganhavam contornos mais nítidos conforme me aproximava de espaços marcados pela fugacidade e pela variedade de público. Espaços que ainda assim, ou melhor, por isso mesmo, materializavam determinada organização de pensamento explicitada nesses espaços ${ }^{17}$ (Marques 2011).

Ao caracterizar os destinos atuais da etnografia, Clifford (2002) chama a atenção para a crise da representação intercultural decorrente da pulverização do privilégio ocidental na descrição e observação do outro, ocorrida com a redistribuição do poder colonial ${ }^{18}$. Em suas palavras: "Com a expansão da comunicação e da influência intercultural, as pessoas interpretam os outros e a si mesmas, numa desnorteante diversidade de idiomas" (Clifford 2002:19).

Recorre-se assim a uma variedade maior de narrativas para a representação de si e representações pelo outro, jogos de imagens sempre insuficientes e relacionais, jogando por terra a idéia de origem. Não é à toa que o autor toma Bakhtin como modelo exemplar daquilo que chama "sincretismo inventivo": um mundo "ambíguo, multivocal", impossível de ser descrito a partir do modelo de "culturas independentes, delimitadas e inscritas" (Clifford 2002: 18-19).

Para o crítico russo, a contribuição do reconhecimento do romance como objeto para a lingüística se dá pela valorização de um gênero cuja riqueza não se encontra em suas particularidades, mas na combinação de várias unidades estilísticas heterogêneas que nele penetram: "A originalidade estilística do gênero romanesco está justamente na combinação destas unidades subordinadas, mas relativamente independentes (por vezes plurilíngües) na unidade superior do "todo"" (Bakhtin 2010: 74). Posteriormente:

Estas ligações e correlações especiais entre enunciações e as línguas (paroles- langues), este movimento do tema que passa através de línguas e discursos, a sua segmentação em filetes e gotas de plurilinguísmo social, sua dialogização, enfim, eis a singularidade fundamental da estilística romanesca (2010: 75).

Nesse horizonte, a substituição do objeto de análise do romance pelo estilo do autor ou pela busca do "estilo do romance", o confundindo com uma de suas unidades subordinadas independentes, seria um completo erro, à medida que embotam a particularidade do gênero como "formação híbrida". Acompanhando um pouco mais o raciocínio de Bakhtin, poder-se-ia pensar que o objetivo do autor é a forma última da interação que compõe o todo. Nada disso. O destino de Bakhtin não é o equilíbrio da linguagem única traduzida por um universo variado, ainda que restrito, de falantes. Para ele:

A língua única não é dada, mas, em essência, estabelecida em cada momento da sua vida, ela se opõe ao discurso diversificado. Porém, simultaneamente ela é real enquanto força que supera este plurilinguísmo, opondo-lhe certas barreiras, assegurando um certo maximum de compreensão mútua e centralizando-se, na unidade real, embora relativa, da linguagem falada (habitual) e da literária "correta" (Bakhtin 2010: 81).

Dessa forma, “Cada enunciação concreta do sujeito do discurso constitui o ponto de aplicação das forças centrípetas, como das centrífugas [da vida linguística]" (Bakhtin 2010: 82). Definido dessa forma, cada ato de fala expressa um lugar de fala de alguém, ao tempo que advinha um universo de compreensão pelo ouvinte. Esse 
lugar não é a expressão original do sujeito, mas espelho da variedade de tensões entre "discurso concreto" e a variedade de encenações da língua considerada pelo falante.

Sem negar as forças centrípetas ou o que chamamos acima de linhas de força, Bakhtin, tal como retomado por Clifford (2002), reconhece as possibilidades criativas do "mau uso da língua"19 em sua tensão na escrita da cultura. Possivelmente, não a cultura em sua realização, mas em sua deriva, em sua impostura, em sua produção multivocal. A sobreposição dessa discussão com nossa etnografia se dá por acreditarmos que a cultura também é escrita, que sujeitos escrevem cultura à medida que reverberam sentidos a partir de sentidos adivinhados no outro, em espaços, em objetos - seja por sua ausência, seja por sua presença. Como Rouch (1995) nos mostrou a verdade da deriva é tão forte como a verdade do ato (Gonçalves 2008). Nesse sentido, o que seria centro, o que seria periferia? O que seria possível decantar para se perceber a "ordem"?

\section{"EM UM AMBIENTE DE MADRUGADA, A GENTE nÃO SABE COM QUEM ESTÁ LIDANDO"- GESTÃO DO ANONIMATO E NARRATIVAS NO GUANABARA}

Voltemos aos poucos para a etnografia, retomando o Guanabara a partir da narrativa de Neto:

Eu: Como você conseguiu o status de sentar-se à mesa [de Neném]? Fora os antecedentes familiares ${ }^{20}$. Neto: Não, Roberto, ali é pra qualquer um que chegue!

Eu: Não! Você acabou de me dizer que não é pra qualquer um... Foi a primeira coisa que você me disse! Neto: Não... Ele é que diz isso... 'Aqui é pro pessoal que é mais íntimo'. Se você não tem grande conhecimento com o Neném, você vai acabar tendo! Ele vai achar um parentesco seu ou com alguém de sua família (...) Então, ali você já vai encontrar uma proximidade com ele, mas digo assim que não é pra todo mundo por que...Bem, teve uma vez que... Isso foi hilário que aconteceu. Eu tava bebendo lá em Correinha ${ }^{21}$ e tinha um menino, a gente chamava ele de 'Neguim', que trabalhava guardando cadeira na Praça da Sé pra Valdir. Ele não tinha nem onde dormir (...) ele já era de maior, trabalhando por uma grana, mas com aquela cara de mal elemento. Ele me chamava até de papai. (...) Peguei amizade com esse cara. Um dia, eu to lá em Correinha, tomando um copo de cana, porque no Guanabara não vendia cachaça, o Neguim chegou e disse: ‘Eu vou pagar a cerveja, mas eu queria beber lá em Neném porque ta passando o jogo [do Brasil com a] da Argentina' (...) E eu disse: 'Pois vá lá, vá beber tua cerveja'. Ele disse: 'Não! Porque lá eu não entro! Não vou entrar não porque ele não deixa eu entrar lá'. 'Então vambora nós dois. E agente vai sentar é na mesa dele! E quando eu cheguei lá, ele [Neném] apontou o dedo pra mim e disse: 'Lóssio'- ele me chama de Lóssio- 'Saiba com quem você se acompanha! Um marginal desses!'. E isso sentado na mesa dele! Ele não sentou nem a pau! (...) Ele foi e disse: 'Eu não sento ai nem a pau!' $E$ eu disse: 'E é ele que ta pagando a cerveja!' . 'Pode ser o Papa, mas eu não sento mas ai enquanto ele não sair!'- Disse o Neném. Na fala de Neto, o Bar sem portas começa a ganhar contornos de definição de seu público. No entanto, se a narrativa nos faz matizar o romantismo sobre o sem limites daquele espaço de sociabilidade, faz pensar também sobre as agências que relacionam o espaço e seu público. Como tais artimanhas transformam e definem a relação com aquele local.

Se, naquela ocasião, a falta de dinheiro impede Neto de beber no Guanabara, se a cor da pele e a origem social não permitem que Neguim entre no bar, associados podem entrar e sentar-se na mesa do Neném, que não 
senta "enquanto ele [Neguim] não sair". Nessa narrativa, o Guanabara é a um só tempo um ambiente elitizado, boêmio e de mistura. Como ainda nos diz Neto:

Se você for parar pra observar... Tem gente que chega ali com problema, gente que chega ali animado, chega gente ali que está a fim mesmo de... Não tá a fim de prostituta de... Por exemplo, eu não vou atrás [de prostituta]! Eu vou escutar a história de um, escutar a história de outro. Escutar aquelas histórias! Ás vezes, eu fico pensando como seria legal se você conseguisse gravar cada figura que você encontrasse no Neném (...) Às vezes tem um cara sozinho lá, eu também estou sozinhho, então eu vou lá conversar. É tanta história! Tem uma riqueza cultural! E é um ambiente! Como eu te disse: [É] a diversidade em si: entra negro, entra homossexual (...) Isso é que é o bonito daquilo ali! O cara que tem o maior preconceito do mundo, ele chega lá nas madruga e vai logo querer... Só [não] se for muito otário... Mas a maioria joga o preconceito fora. Isso eu digo por que conheço pessoas quando é fora, preconceituosos ao extremo em termos de religião, em termos de cor e quando chega lá, de repente ele está conversando com uma pessoa que ele teria preconceito [se estivesse] bom, mas lá! Já com umas na cabeça... Isso é que eu acho legal! (...) Porque aquilo ali é cultural dentro do Crato! O Neném Guanabara é cultural dentro do Crato. O Crato já foi a terra da boêmia e o Neném foi um dos pioneiros aqui dentro do Crato.

$\mathrm{Na}$ fala de Neto, as formas surpreendentes de encontros entre as pessoas, possibilitados pelo bar, ocupam o status de algo "cultural" no Crato. Estranha conjunção que alia um espaço elitizado ao lado de uma zona de alta prostituição na década de 1940, um personagem boêmio que ancora e cria o cenário para tais narrativas e a produção em ato de personagens insuspeitos. Mas, conforme tentamos demonstrar em pesquisas anteriores (Marques 2011), em um espaço que potencializa a indistinção, faz-se necessário estabelecer formas de reconhecimento entre pares. Continuemos a ouvir Neto:

Eu: É comum ele não servir [algumas] pessoas?

Neto: Pessoas de baixo poder aquisitivo ou que criem confusão... É comum! Eu já vi várias vezes ele dizer que não vai atender. Os próprios garçons dizem: 'Olha, isso aqui não tem'. Quando ele vê a pessoa e diz: 'Aquele ali é cafuçu, eu não vou atender'. Acho que ele observa mais a forma de se vestir, às vezes a pessoa vai até com intenção de gastar mais (...). Ele já não deixa entrar no bar e fica de cara feia quando estão atendendo. Isso acontece quando ele está no recinto. Quando ele não está, o pessoal [os garçons] já abre mais as pernas, sabe? Quando está por conta dos garçons, ai fica mais maleável em relação a isso.

Eu: Mas eu já vi também, na ausência dele, a pessoa querer comprar cerveja em pé [para tomar em outro local que não o bar] e o garçom não vender. Não era nem pra beber ali. A pessoa então foi lá no carro, veio outro acompanhante e comprou a cerveja pra que ele pudesse beber sua cerveja em outro local.

Neto: Isso sempre acontece.

Eu: Isso me interessa, não pra falar mal do ambiente, mas pra entender o lugar. Em princípio, aquele é um ambiente que seria pra todo mundo.

Neto: E acaba não sendo, né? Se é aberto 24 horas e é pra ser pra todo mundo! Ali você não está pagando uma mensalidade pra você... Não é uma coisa privada! Se não fosse pra todo mundo, ele colocaria uma porta! Nem porta tem! Não sei se você já notou! Esse tempo todinho que existe Neném Guanabara não tem porta! Isso é até um paradoxo! Não tem porta, mas eu não posso entrar. É aberto, mas eu não posso entrar. É invocado!

Vale a pena observar quantas intenções percorrem a narrativa de Neto. Se algumas frases eliciam o saudosismo da "Cidade da Cultura 22 no tempo da boêmia" ("aquilo ali já mudou tanto"), na mesma oração Neto é atravessado pela valorização da diversidade no bar ("Agora é que tá bom!"), ainda que essa diversidade implique em violência (“O Guanabara é um local violento”). 
Se a impossibilidade de entrar no bar para alguns parece um paradoxo, o incômodo com isso dá lugar, frases adiante, à romantização do bar sem portas ("Se não fosse pra todo mundo, ele colocaria uma porta! Nem porta tem! Não sei se você já notou! Esse tempo todinho que existe Neném Guanabara não tem porta"...). Neto parece ser agenciado por sucessivas linguagens com distintas intenções, linguagens à disposição quando o Guanabara se faz mote para analogias.

Em outra noite, fui com Sônia ${ }^{23}$ ao Guanabara. Falando sobre o bar, instigando-a sobre o lugar, pedi que ela tirasse fotografias do local. Atentos ao entra e sai de clientes no bar, a diversidade de condutas naquele ambiente absolutamente banal de fim de noite, fomos surpreendidos por um grupo de três senhoras, entre 35 e 50 anos, morenas, com roupas bastante simples que se sentaram na primeira mesa, à porta da rua. A mais velha das senhoras foi até o caixa, conversou algo com o garçom e em seguida uma cerveja foi levada a mesa delas. Interessado na cena, pedi a Sonia que fosse até lá, conversasse com elas e pedisse pra bater uma foto. Ela assim o fez: "Não, minha filha, de jeito nenhum!" - respondeu a mais velha das senhoras - "E se eles descobrirem que a gente está aqui?!".

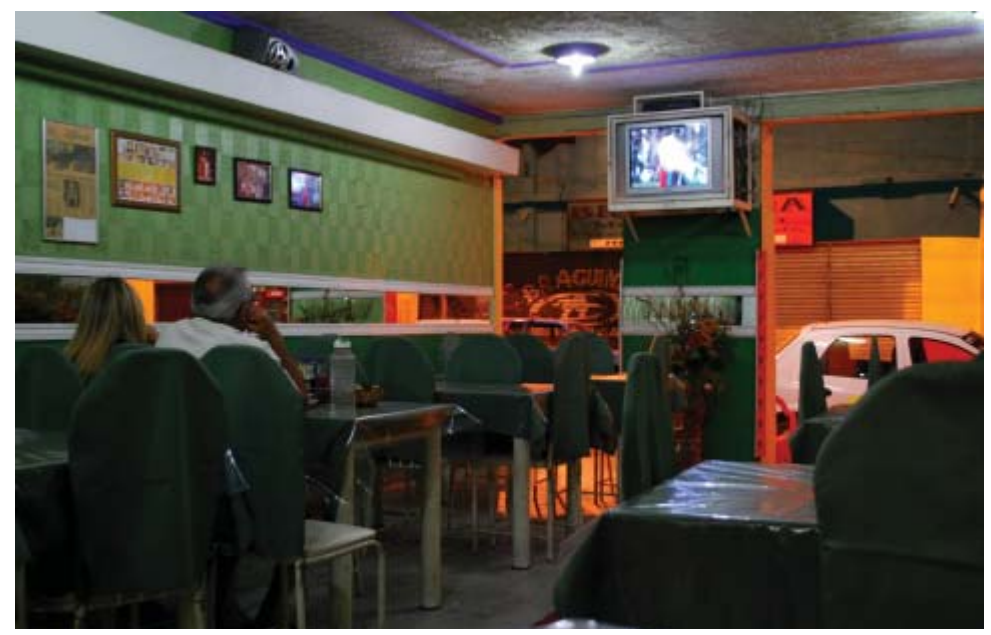

Casal assiste televisão no Guanabara

Aparentemente, naquele espaço, pessoalidade não é em absoluto o oposto de impessoalidade. Os corpos à porta do Guanabara, em uma rua central de Crato, parecem se tornar invisíveis para a cidade, contanto que não sejam cristalizados pelo flash da máquina fotográfica ${ }^{24}$. Estar ou não estar ali depende de ações concretas dos sujeitos, em sua relação com o ambiente, a partir do contato com outros sujeitos. Nesse cenário, o que é desejável? A exata sobreposição entre as atitudes do sujeito e o lugar onde ele deveria reconhecidamente estar, ou a possibilidade/desenvoltura de estar em vários lugares ao mesmo tempo? 
A esse respeito, Neto surpreende outra artimanha:

Mais outra questão das mesas. Não sei se você notou que do lado esquerdo de quem está entrando ${ }^{25}$, esse ambiente ali é justamente o ambiente pra quem não quer ser visto! Não é? Um ambiente que é mais reservado e tal. Geralmente nesse ambiente, que era pra andar as prostitutas com seus acompanhantes, nunca ficam ali! Eles ficam é no meio da fuzarca! Ali na frente. Aquilo ali teve uma época em que aconteceu foi o contrário! O pessoal chegava pra jantar com a família no Neném Guanabara e o pessoal ficava ali, justamente pra não querer aparecer, porque ali tinha uma quantidade de rapariga, tá entendendo? Tinha uma algazarra e ai [as pessoas com seus familiares] ficava [m] lá. E o objetivo principal, quando você coloca um reservado é você querer uma privacidade, mas ali aconteceu foi o contrário!

Como se pode perceber, o convívio de realidades distintas em um espaço limitado exige a idealização pelos frequentadores de uma mínima gramática comum a obedecer. Como vimos com Bakhtin (2010) acima, essa gramática é composta sempre por linguagens postas em ato na relação com o outro, a partir de seus marcadores ou da idealização de como acessar tais marcadores. Composição que implica imagens e disputas, ali presentes ou ausentes, em um espelhamento entre linguagens, intenções e imagens.

Essas intenções são explicitadas tanto pelas narrativas quanto pela presença, ou jogos de presença-ausência, ao revelar-se no salão principal do Guanabara - como fizeram as garotas de programa descritas por Neto acima; ao formar pares para poder entrar no restaurante, como fez Neguim; ao negarem ser captadas pela máquina fotográfica, como fizeram as senhoras no Guanabara. Ao compor o bar com suas imagens, as personagens aqui dispostas materializam uma imagem do local em que moram a partir de suas (im) possibilidades de trânsito. Tal engenho nos ajuda a pensar sobre formas de organização em situações de borda, ainda que não se esteja falando aqui em absoluto de uma situação marginal, pouco frequente ou pouco ruidosa na região do Cariri.

Certamente esses espaços rompem com alguns marcos da reflexão sobre Nordeste como região de atraso ou desafio à modernidade, refúgio do mundo patriarcal, como uma história em ritmo lento ou ainda como um ambiente reativo à modernidade. Ao contrário, por vezes a dinâmica aqui etnografada torna-se um desafio as nossas possibilidades de classificação, a rapidez de nossa caneta, bem como aos sistemas de oposição de nosso raciocínio.

Não diríamos que é um outro Nordeste, antes que é um também Nordeste. Um Nordeste de limites incertos por sua porosidade e capacidade de agregar diferenças. Dessa forma, os espaços aqui descritos parecem estar também à margem da definição usual da região do Cariri e se distanciar de determinada leitura sobre Nordeste a partir de noções como comunidade, cultura popular ou mundo rural, leituras bastante difundidas no Brasil.

À medida que consideramos a produção de "muitos outros" [da nação] (Pratt, 1999a) ainda que sempre dependentes de alegorias, torna-se possível pensar o Guanabara como forma de acessar uma imagem interpretativa do Cariri pelos próprios nativos. E ainda perceber as possibilidades e dispositivos criados por eles na ancoragem de territórios da pessoalidade e a necessidade de reinvenção de si e dos signos que os constituem a partir de territórios de sombra. Etnografo, pois, o Guanabara através de seus trânsitos e apropriações, por relações sensíveis e concretas, tentando cruzar marcadores e espacialidades a partir da ação dos sujeitos, de forma a não encerrálos em espacialidades ou marcadores pré-definidos, apreendendo as paisagens humanas a partir da mediação de personagens e não somente como cenários pré-existentes a eles. 
Tentei aqui, portanto, a partir das paisagens sonoras da música romântica do Guanabara, da percepção de imagens que refletem imagens por um listelo de espelhos, pensar o Cariri de forma a não estancar as narrativas dos sujeitos. Fazendo eco à fala de Neto acima: pensar a dinâmica da operação entre marcadores como algo "cultural" no Cariri. Se por um lado, aprendemos com Said (1990), Bourdieu (1998) e Foucault (1979a; 1979b) que tal operação é composta por imagens em relações de força historicamente situadas, essa composição de forças realça a necessidade de estabelecer relações dialógicas (Clifford 2002: 49-54) com os atores, de modo a compor novas alegorias, conferindo-Ihes alcance, para que a imagem de uma relação de contornos históricos pouco evidentes não reine sobre nosso imaginário sobre o Cariri. Aparentemente, o Guanabara pode ser um bom antídoto para esse mal. 


\section{NOTAS}

1 Não pretendo com essa localização acessar um mapa mental previamente disponível pelo leitor, mas demonstrar que tipos de estabelecimentos são utilizados para dar referências de localização na cidade de Crato. No caso, indicam-se a única filial do banco citado ali presente ou um estabelecimento comercial local, que serve como referência no centro da cidade ao longo de décadas.

2 Os nomes aqui citados são todos verdadeiros, tendo seu uso sido autorizado pelas pessoas mencionadas.

3 De acordo com Censo do Instituto Brasileiro de Geografia e Estatística de 2010

4 De acordo com Facó (2009), entre os anos de 1890 e 1898, Juazeiro do Norte duplicou em população, alcançando 5.000 habitantes. Em 1905, a cidade possuía 12.000 habitantes e em 1909, 15.000. (2009: 137-227). De acordo com o Censo 2010, a cidade contabiliza atualmente algo em torno de 249. 939 habitantes, tendo crescido mais que qualquer outra na região.

5 Silva reforça em nota de rodapé: "O único trabalho semelhante [ao presente artigo] que conheço, embora com ambições bastante diversas, é o artigo de Cara E. Richards: City taverns (...)" (Silva 1969: 160).

6 Vale salientar ainda o uso que White (2005) faz de bares e lanchonetes em seu clássico estudo Sociedade de Esquina.

7 A configuração aqui descrita é constituinte da própria consolidação da antropologia brasileira, tal como aponta Perlongher (1987) no texto acima citado. Assim, como estratégia para se pensar uma determinada comunidade se utiliza ora da ideia de comunidade como um todo fechado, ora dos marcadores gênero e/ou sexualidade como limites de sociabilidade. São evidentes os avanços alcançados com essa estratégia metodológica, no entanto, como tento deixar claro ao longo do texto, a reflexão sobre o Guanabara e demais ambientes etnografados no Cariri (Marques 2011) parece exigir um recorte metodológico diferente.

8 Lima Junior é professor do Curso de Economia da Universidade Regional do Cariri. Ao mesmo tempo, nascido em Cariús, é nativo do centro-sul do Estado do Ceará, tendo sido também morador de república estudantil durante sua formação em Economia na cidade do Crato. Gentilmente, acompanhou-me em muitas de minhas incursões em campo, sendo a um só tempo interlocutor privilegiado e nativo dessa pesquisa.

9 Importante salientar que essa narrativa, instigada pelo pesquisador, trata-se de uma "fabulação" de Lima Junior: localização de nativos por outro nativo a partir de indícios reconhecidos no outro.

10 Conforme me alertou um dos pareceristas do presente artigo, a ideia aqui utilizada de trejeitos, assim como a de afemininado, tem sempre como referência um comportamento espacial e socialmente localizado de atitudes próximas à masculinidade hegemônica. Para tal discussão, ver, por exemplo, Connell (1995) e Marques (2008).

11 Utilizo aqui recurso metodológico empregado por Silva (1969), ao afirmar que toda análise de casas de bebida deve considerar a duração e a intensidade da permanência da clientela, o que configuraria diferentes tipos de estabelecimentos a partir da existência ou ausência de clientes fixos. A terminologia "bares de bairro" por mim empregada, seria, portanto, o estabelecimento frequentado majoritariamente por um grupo fixo de pessoas que mantém uma sociabilidade constante por morarem na proximidade do bar, utilizado como local de lazer. Em cidades de pequeno e médio porte, cujos bairros não possuem comércio ou equipamentos urbanos independentes, esses estabelecimentos se opõem àqueles situados no centro da cidade ou áreas confluentes de diversos tipos de comércio, como farmácia, restaurante, bancos etc.

12 O Carnaval da Saudade é um baile de pré-carnaval organizado pelo Crato Tennis Clube, clube de veraneio na parte central da cidade de Crato, existente desde a década de 1950. Ao final do baile, foliões de diferentes gerações saem às ruas da cidade, dançando fantasiados, animados pela banda da festa.

13 O "Gesso" é a forma usual de referir-se ao bairro Pinto Madeira, entre o trilho do metrô ou o Largo da RFFSA (Rede Ferroviário Federal) e a rodoviária da cidade. Desde a década de 1940, o bairro conta com zonas de prostituição (Andrade 2000) e, mais recentemente, é também conhecido como espaço para comercialização de drogas. Sobre a localização do Guanabara, é importante também salientar sua proximidade com armazéns na zona mais periférica do centro, onde funcionam durante o dia bares com sinuca, lojas de confecções bastante populares, lojas para a venda de selas de cavalo, enxadas e foices. Localiza-se ainda a dois quarteirões do canal do Rio Granjeiro, onde funciona a feira da cidade às segundas-feiras. O bar se encontra em uma zona de entroncamento, à 
entrada da rua que dá acesso à cidade de Crato aos transportes vindos de municípios como Santana do Cariri, Nova Olinda, Farias Brito, Iguatu e distritos como Dom Quintino, Campo Alegre, Ponta da Serra; e aos bairros populares da Batateira e Independência, pela Ladeira da Integração.

14 Cidade localizada no interior paulista, Cunha foi fundamental para a caracterização dos estudos de comunidades ou bairros rurais a partir da oposição entre vida urbana e rural, realçadas aqui na citação de Prado a partir da ideia de pessoalidade. Sobre o tema, ver Willems (1947) e Shirley (1977).

15 Nascidos, respectivamente, nas cidades de Assaré (CE); Exu (PE) e Crato (CE).

16 Para um quadro sociológico mais preciso da região, vide: Della Cava (1976), Marques (2004b), Slater (1986) e Barros (1988).

17 Vale ressaltar que a forma de pensamento expressa nesse lugar, não necessariamente caracteriza esse lugar.

18 Além da redistribuição do poder colonial citada, Clifford (2002) atribui a nova sensibilidade etnográfica às repercussões das teorias culturais radicais dos anos 60 e 70.

19 Expressão utilizada por Bakthin (2010).

20 Como citado acima, Neto afirma ser da terceira geração de sua família a frequentar o Guanabara.

21 Correinha é um bar que funcionou em frente ao Guanabara. Antes disso, funcionava em uma das esquinas em frente à Praça da Sé. Em 2010, com a morte do proprietário, o "Correinha" fechou. Nessa mesma entrevista, Neto diz que Neném sempre afirmava que "a mundiça lá de Correinha é que faz a briga". Neto continuou: "E eu chegava lá em Correinha e contava pra Correinha. Ele dizia: 'Pois eu não dou cinco minutos pra os riquinhos de Neném começarem a brigar!'”

22 A cidade de Crato possui a alcunha de 'Cidade da Cultura', 'Pérola do Cariri', entre outras - por seu pioneirismo em termos de educação e urbanização no interior do Ceará. A esse respeito, ver Cortez (2000) e Marques (2004b).

23 Sônia Meneses é professora do departamento de História da Universidade Regional do Cariri. Gentilmente, acompanhou-me a algumas incursões em campo, particularmente registrando imagens dos ambientes estudados, como podemos ver, por exemplo, no presente artigo. Nesse artigo em específico, chamo a atenção para o uso da máquina fotográfica como recurso metodológico de entrada em campo, possibilitando, por exemplo, o diálogo com as senhoras na mesa sobre a apropriação de sua imagem no ambiente do bar. A este respeito, ver Gonçalves (2008).

24 Nesse sentido, esse bar de fim de noite assemelha-se aos forrós eletrônicos, esse espaço de (in)distinção que parece potencializar o que chamamos acima gestão do anonimato. Tal reflexão permite que esse ritmo, muitas vezes pensado apenas como um efeito da indústria cultural, seja pensado a partir das relações que permitem sua ampla recepção e difusão no Cariri, em shows que chegam a juntar 70.000 pessoas. Para maiores informações sobre o tema, vide Marques (2011).

25 Retomar a planta-baixa do bar acima. 


\section{REFERENCIAS BIBLIOGRAFICAS}

ALBuQUeroue JR, Durval Muniz de. 2001. A invenção do Nordeste e outras artes. Recife: Masangana; São Paulo: Cortez.

ANDRADE, larê Lucas de. 2000. Da linha do trem pra lá: O discurso sobre a prostituição na cidade de Crato (1940/1960). Dissertação de Mestrado em História Social. Rio de Janeiro: Instituto de Filosofia e Ciências Humanas, Universidade Federal do Rio de Janeiro.

BAKTHIN, Mikhail. 2010. Questões de literatura e de estética: a teoria do romance. São Paulo: Hucitec.

BARBOSA, Francisco Salatiel de Alencar. 2007. O Joaseiro celeste: tempo e paisagem na devoção ao Padre Cícero. São Paulo: Attar.

BARROS, Luitgarde Oliveira C. 1988. A terra da mãe de Deus. Rio de Janeiro: Francisco Alves; Brasília: INL.

BENÍTEZ, Elvira. 2007. "Buraco da Lacraia”. In G. VELHO (org.). Rio de Janeiro: cultura, política e conflito. Rio de Janeiro: Jorge Zahar.

BOURDIEU, Pierre. 1998. "A identidade e a representação. Elementos para uma reflexão crítica sobre a ideia de região". In O Poder simbólico. Rio de Janeiro: Bertrand Brasil.

CLIFFORD, James. 2002. A experiência etnográfica: Antropologia e literatura no século XX. Rio de Janeiro: Editora UFRJ.

CONNELL, Robert. 1995. "Políticas de Masculinidade". Educação e Realidade 20(2): 185-206.

CORDEIRO, Maria Paula Jacinto, 2011. Entre chegadas e partidas: dinâmicas das romarias em Juazeiro do Norte. Fortaleza: Imeph.

CORTEZ, Antonia Otonite de Oliveira. 2000. A construção da Cidade da Cultura: Crato (1889-1960). Dissertação de Mestrado em História Social. Rio de Janeiro: Instituto de Filosofia e Ciências Sociais, Universidade Federal do Rio de Janeiro.

DELLA CAVA, Ralph. 1976. Milagre em Joaseiro. Rio de Janeiro: Paz e Terra.

FACÓ, Rui. 2009 [1963]. Cangaceiros e fanáticos: gênese e lutas. Rio de Janeiro: Ed. UFRJ.

FACCHINI, Regina. 2008. Entre Umas e Outras: mulheres, (homo)sexualidades e diferenças na cidade de São Paulo. Tese de Doutorado em Antropologia. Campinas, SP: Instituto de Filosofia e Ciências Humanas, Universidade Estadual de Campinas.

FOUCAULT, Michel. 1979a. "Sobre a geografia". In R. Machado (org.) Microfísica do Poder. Rio de Janeiro: Graal. 1979b. “Verdade e poder". In R. Machado (org.) Microfísica do Poder. Rio de Janeiro: Graal.

FRANÇA, Isadora Lins. 2009. "Na ponta do pé: quando o black, o samba e o GLS se cruzam em São Paulo". In Maria Elvira e Carlos Eduardo Figari (orgs.) Prazeres Dissidentes. Rio de Janeiro: Garamond.

FRY, Peter. 1982. Para Inglês ver. Rio de Janeiro: Zahar. 
GASPAR. Maria Dulce. 1985. Garotas de Programa. Prostituição em Copacabana e Identidade Social. Rio de Janeiro: Jorge Zahar.

GONÇALVES, Marco Antônio Teixeira. 2008. O real imaginado: Etnografia, cinema e surrealismo em Jean Rouch. Rio de Janeiro: Topbooks.

MARQUES, Roberto. 2004a. "A Identidade como estratégia: Modernização, Memória e Política no Cariri (1950)". In Marinalva Vilar de Lima e Roberto Marques (orgs.) Estudos Regionais: Limites e Possibilidades. Crato, CE: NERE/ Ceres.

2004b. Contracultura, tradição e oralidade: (re)inventando o sertão nordestino na década de 70. São Paulo: Annablume.

2008. "Entre a ordem social e os afetos: o patriarcalismo como metáfora". In: Liliana da Escóssia e Eduardo Leal Cunha (orgs.) A psicologia entre o indivíduo e sociedade. São Cristóvão: Ed. UFS.

2009. “Deslocando corpos e significados: espaço, tempo e política entre romeiros do padre Cícero”. Religião \& Sociedade 29: 256-260.

2011. O Cariri do forró eletrônico: Festa, gênero e criação no Nordeste contemporâneo. Tese de Doutorado em Antropologia Cultural. Rio de Janeiro, RJ: Instituto de Filosofia e Ciências Sociais, Universidade Federal do Rio de Janeiro.

MARTINS, Edson Soares. 2003. “O cordel, o homossexual e o poeta 'maudito': novelo de discursos no folheto de Salete Maria e Fanka Santos". Estudos de Literatura Brasileira Contemporânea 22: 125-136.

OLIVEIRA, Leandro de. 2006. Gestos que pesam: Performances de gênero e práticas homossexuais em contexto de camadas populares. Dissertação de Mestrado em Saúde Coletiva. Rio de Janeiro, RJ: Instituto de Medicina Social, Universidade Estadual do Ceará.

PAZ, Renata Marinho. 2011. Para onde sopra o vento: Igreja Católica e romarias em Juazeiro do Norte. Fortaleza: IMEPH.

PENNA, Maura. 1992. O que faz ser nordestino: identidades sociais, interesses e o 'escândalo' Erundina. São Paulo: Cortez.

PERLONGHER, Nestor. 1984. "Antropologia das Sociedades complexas: Identidades e territorialidade, ou como estava vestida Margaret Mead". In: <www.anpocs.org.br/portal/publicacoes/rbcs_00_22/rbcs22_08.htm>. Acessado em 09/07/2008.

1987. O negócio do michê: A prostituição viril. São Paulo: Brasiliense.

PRADO, Rosane Manhães. 1997. “Cidade pequena: paraíso e inferno da pessoalidade”. Cadernos de Antropologia e Imagem 4: 31-54.

PRATT, Mary Louise. 1999a. "Pós-colonialidade: projeto incompleto ou irrelevante?" In Luiz Eugênio VÉSCIO e Pedro Brum Santos (orgs.) Literatura \& História: perspectivas e convergências. Bauru, SP: EDUSC. 
PRATT, Mary Louise. 1999b. Os olhos do império: relato de viagem e transculturação. Bauru: EDUSC.

RAGO, Margareth. 2001. “Prefácio: Sonhos de Brasil”. In Durval Muniz de Albuquerque Jr. A invenção do Nordeste e outras artes. Recife: FJN, Masangana. São Paulo: Cortez.

ROUCH, Jean. 1995. "54 anos sem tripé". Cadernos de Antropologia e Imagem 1: 65-74.

SAID, Edward. 1990. Orientalismo: O Oriente como invenção do Ocidente. São Paulo: Companhia das Letras.

SHIRLEY, Robert. 1977. O fim de uma tradição. São Paulo: Perspectiva.

SILVA, Luiz Antônio Machado da. 1969. “O Significado do Botequim”. Revista América Latina 12(3): 160-182.

SLATER, Candace. 1986. Trail of miracles: Stories from pilgrimage in northeast Brazil. Berkeley: University of California Press.

SOUZA, Rolf Ribeiro de. 2003. A Confraria da esquina: O que os homens de verdade falam em torno de uma carne queimando - etnografia de um churrasco de esquina no subúrbio carioca. Rio de Janeiro: Bruxedo.

STRATHERN, Marilyn. 2005. Partial Connections. California: Altamira Press.

2006. O Gênero da Dádiva. Campinas: Ed. Unicamp.

WHITE, William Foote. 2005 [1943]. Sociedade de esquina: a estrutura social de uma área urbana pobre e degradada. Rio de Janeiro: Jorge Zahar.

WILLEMS, Emílio. 1947. Cunha: Tradição e transição em uma cultura rural no Brasil. São Paulo: Secretaria de Agricultura, Diretoria de Publicidade Agrícola.

WOORTMANN, Ellen. 1995. Herdeiros, Parentes e Compadres. São Paulo: Hucitec. 


\section{Comunidade sem portas: imaginando o cariri a partir de um bar de fim de noite}

\section{RESUMO}

Em Crato (CE), encontra-se um bar aberto 24 horas. O "Guanabara" não tem portas, servindo bebidas e refeições o dia inteiro ao som de Altemar Dutra, Roberto Carlos e Nelson Gonçalves. Em 2010, o bar completou 52 anos de existência. Informados pelas contribuições de Bourdieu, Said e Foucault para pensar espacialidades como reapresentações calcadas em signos identitários, interessa-nos refletir como tais signos funcionam em lugares de confluência para grupos distintos e concomitância de gramáticas sociais. Para isso, recorremos a autores como Clifford e Bakthin, a fim de tencionar as imagens usuais do Cariri e do Nordeste com alegorias postas em ação nesse modelo de comunidade sem portas.

PALAVRAS-CHAVE: bares; espacialidades; alegorias; anonimato; Cariri

\section{Community with no doors: imagining the region of Cariri from a night-over bar in Crato.}

\section{ABSTRACT}

In the town of Crato (State of Ceará), there is a bar that remains open 24 hours. The "Guanabara" has no doors and serves drinks and meals all day long to the sound of artists such as Altemar Dutra, Roberto Carlos and Nelson Gonçalves. In 2010, the bar completed 52 years of existence. Supported by the contributions of Bourdieu, Foucault and Said to think spatialities as moments of presenting signs of identity, we aim to reflect about how these signs work in places of convergence for different groups and in consonance with their social grammars. For this purpose, we draw on authors such as Clifford and Bakhtin, in order to provoke tension over the common images of the Cariri region and Northeast Brazil by the use of allegories set in motion by this model of a community without doors.

KEYWORDS:bars; spatialities; allegories; anonymity; Cariri region.

Recebido em: 11/02/2011 